\title{
THE EFFECT OF WORK STRESS ON EMPLOYEE PERFORMANCE IN PT BANK PEMBIAYAAN RAKYAT SYARIAH SYARIKAT MADANI KOTA
} \section{BATAM}

\author{
$1^{\text {st }}$ Yogi Ardiyan \\ Departement of Applied Business Administration \\ Batam State Polytechnic \\ Batam City, Riay Island Indonesia \\ Yogiardiyan22@gmail.com
}

\author{
$2^{\text {nd }}$ Maryani Septiana, S.Sos., M.Hum \\ Departement of Applied Business Administration \\ Batam State Polytechnic \\ Batam City, Riay Island Indonesia \\ maryaniseptiana@polibatam.ac.id
}

\begin{abstract}
This research aims to determine the effect of work stress on employee performance at PT. BPRS Syarikat Madani Batam city. The data analysis method used is multiple linear regression analysis. The samples in this research were 39 respondents. Data collection in this research used a questionnaire, observation, and documentation. The results showed that there are a positive and significant effects between environmental factors and employee performance, there is a positive and not significant influence between organizational factors and employee performance, and there is a positive and significant influence between personal factors and employee performance. Furthermore, all three factors have a positive and significant influence simultaneously.
\end{abstract}

Keywords- Work Stress, Environmental Factors, Organizational Factors, Personal Factors, Employee Performance

\section{INTRODUCTION}

\section{A. Background}

In the current era, every employee who works in a company must be productive in carrying out all tasks or jobs. Besides having to be productive, every employee will face a routine every day for an indefinite period of time. This phenomenon will usually cause pressure in work. Work pressure and saturation of routines often become stressors at work. Not only those factors, family problems also add to the list of stressors at work.

According to Robbins [1], stress is a condition that experiences dynamics when someone is confronted with a desired demand, constraint, and opportunity but the results cannot be ascertained and are important. Usually, if an employee feels excessive work stress, it will affect his overall performance.
According to Mathis \& Jackson [2], performance is something that must be done by employees to achieve the target by combining the capabilities, efforts, and support of the company. The phenomenon of employee performance that often occurs at this time is marked by a decrease in the quality of work that affects the work results of these employees. The decline in the quality of work in question, for example, is to provide poor service to customers, difficult to achieve targets, work results that are not satisfactory for the company and so forth. Job stress has a close relationship with employee performance. If the stress level is high, it causes low employee performance. In this condition there is a decrease in performance. Excessive stress levels cause employees to be depressed, because they are no longer able to handle tasks that are too heavy. However, if the stress level is low, then the performance of employees also tends to decrease due to lack of effort in facing work challenges.

In this study, the company that became the object of research was PT. BPRS Syarikat Madani or commonly known as Bank Syarikat Madani which is a company engaged in banking that adheres to the system of sharia and Islamic muamalah or also called a sharia public funding bank. It is seen from the achievement of targets set by the company.

From the background it has been stated, then this becomes a provision interested in conducting research entitled "The Effect of Job Stress on Employee Performance in PT. BPRS Syarikat Madani Kota Batam".

\section{B. Formulation of the problem}

Based on the background stated earlier, the problems formulated in this study are:

1. Do environmental factors affect the performance of employees at PT. BPRS Syarikat Madani Batam city? 
2. Do organizational factors affect the performance of employees at PT. BPRS Syarikat Madani Batam city?

3. Do personal factors affect the performance of employees at PT. BPRS Syarikat Madani Batam city?

4. Do environmental factors, organizational factors, and personal factors influence the performance of employees at PT. BPRS Syarikat Madani Batam city?

\section{Objective of the Study}

The objectives of this study are:

1. To find out the influence of environmental factors on the performance of employees at PT. BPRS Syarikat Madani, Batam city.

2. To find out the influence of organizational factors on the performance of employees at PT. BPRS Syarikat Madani, Batam city.

3. To find out the influence of personal factors on the performance of employees at PT. BPRS Syarikat Madani, Batam city.

4. To find out the influence of environmental factors, organizational factors, personal factors on the performance of employees at PT. BPRS Syarikat Madani, Batam city.

D. Significance of the study

The benefits of this study are:

1. Practical Benefits

Providing input, contributions and information for companies regarding work stress issues on employee performance at PT. BPRS Syarikat Madani, Batam city.

\section{Theoretical Benefits}

Expand and add insight to science, especially in studies related to work stress and employee performance. In addition, this research is expected to be useful for further research.

\section{REVIEW OF LITERATURE}

\section{A. Job stress}

According to Handoko [3] work stress is a person's condition, thought process and emotion that is influenced by tension conditions, thus disturbing someone in carrying out their duties and threatening ability due to the results of excessive stress.

In the opinion of Robbins [1] there are three categories of potential job stress triggers, namely:

1. Environmental factors

2. Organizational factors

3. Personal factors

\section{B. Employee performance}

1. According to Sedarmayanti [4] performance is the result of work achieved by a person / group of people in an organization in accordance with their respective authority and responsibility in order to achieve the objectives of the organization concerned, Environmental Factors, Organizational Factors, and Personal Factors

H0: There is a positive and not significant influence between environmental factors, organizational factors, and personal factors on the performance of employees at PT. BPRS Syarikat Madani, Batam city.

H4: There is a positive and significant influence between environmental factors, organizational factors, and personal factors on the performance of employees at PT. BPRS Syarikat Madani, Batam city.

legally, not violating the law, and according to morals and ethics.

According to Robbins [5], the dimensions of employee performance are divided into 3, namely:

1. Quantity of work

2. Quality of work.

3. Timeliness

\section{Effect of Job Stress on Employee Performance}

According to Handoko [6], when an employee has experienced work stress that affects his performance, work stress can provide functional and functional effects. Functional stress in work is when stress is helping an employee to improve his performance, while the functional stress is work that is destructive or inhibits the performance of an employee. This depends on how much the level of stress experienced by the employee.

\section{Conceptual Framework}

The mind framework of this study described in chart as follows :

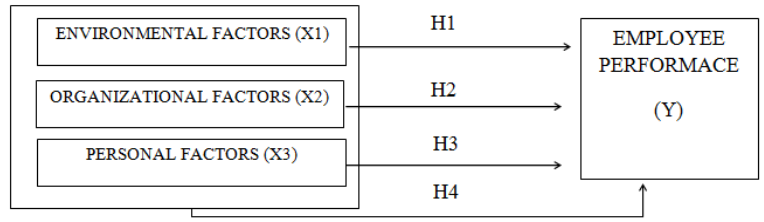

Fig. 1. Conceptual Framework

\section{E. Hypothesis}

The hypothesis in this study are as follows:

1. Environmental Factors (X1)

H0: There is a positive and not significant effect between environmental factors on the performance of employees at PT. BPRS Syarikat Madani, Batam city.

H1: There is a positive and significant influence between environmental factors on employee performance at PT. BPRS Syarikat Madani, Batam city.

2. Organizational Factors (X2)

H0: There is a positive and not significant effect between organizational factors on the performance of employees at PT. BPRS Syarikat Madani, Batam city.

H2: There is a positive and significant influence between organizational factors on employee performance at PT. BPRS Syarikat Madani, Batam city. 
3. Personal Factors (X3)

H0: There is a positive and not significant effect between personal factors on the performance of employees at PT. BPRS Syarikat Madani, Batam city.

H3: There is a positive and significant influence between personal factors on employee performance at PT. BPRS Syarikat Madani, Batam city.

4. Environmental Factors, Organizational Factors, and Personal Factors

H0: There is a positive and not significant influence between environmental factors, organizational factors, and personal factors on the performance of employees at PT. BPRS Syarikat Madani, Batam city.

H4: There is a positive and significant influence between environmental factors, organizational factors, and personal factors on the performance of employees at PT. BPRS Syarikat Madani, Batam city.

\section{METHODS OF RESEARCH}

\section{A. Research Design}

The research design used in this study is quantitative research with a descriptive approach. According to Sugiyono [8], quantitative methods are methods used to examine population and samples that are the object of research, research instruments as data collection, statistical tests as analytical tools that aim to test predetermined hypotheses. While the descriptive understanding according to Nazir [7] is an object, set of conditions, systems of thought, group of people studied, and current events that serve as research methods.

\section{B. Objects and Scope of Research}

The object of this research is employees of PT. BPRS Syarikat Madani, Batam City, while the scope of this research is the performance of employees of PT. BPRS Syarikat Madani, Batam city.

\section{Population and Sample}

In this study the population is respondents who are employees of PT. BPRS Syarikat Madani Batam city. The sampling technique uses a saturated sampling technique because all members of the population become respondents.

\section{Data Collection}

\section{Questionnaire:}

The questionnaire is a collection of written statements or questions to be answered by respondents as a way to conduct data collection techniques. In this study the answers to closed questions will be measured using the Likert scale [8].

\section{E. Validity and Reliability}

Validity test is a test that uses a measuring instrument in the form of a questionnaire with the aim of measuring valid or invalid data. Reliability is a variable that comes from an indicator to be measured using a questionnaire as a measuring instrument. The following are the results of the calculation of the validity and reliability test tested with SPSS version 20 in the form of a table:
TABLE I. VALIDITY \& RELIABILITY TEST RESULT RESULT

\begin{tabular}{|c|c|c|c|c|c|}
\hline \multirow{2}{*}{$\begin{array}{c}\text { Variab } \\
\text { le }\end{array}$} & \multicolumn{4}{|c|}{ Validity } & \multirow{2}{*}{$\begin{array}{l}\begin{array}{c}\text { Reliabil } \\
\text { ity }\end{array} \\
\text { Alpha } \\
\text { Cronba } \\
\text { ch }\end{array}$} \\
\hline & Item & $\begin{array}{c}r \\
\text { count }\end{array}$ & r table & $\begin{array}{c}\text { Decisi } \\
\text { on }\end{array}$ & \\
\hline \multirow{2}{*}{$\begin{array}{l}\text { Enviro } \\
\text { nmental }\end{array}$} & $\mathrm{X} 1.1$ & 0,703 & 0,3160 & Valid & \multirow{2}{*}{$\begin{array}{c}0,814 \\
\text { Reliable }\end{array}$} \\
\hline & $\mathrm{X} 1.2$ & 0,646 & 0,3160 & Valid & \\
\hline \multirow{4}{*}{$\begin{array}{l}\text { Factors } \\
(\mathrm{X} 1)\end{array}$} & $\mathrm{X} 1.3$ & 0,763 & 0,3160 & Valid & \\
\hline & $\mathrm{X} 1.4$ & 0,723 & 0,3160 & Valid & \\
\hline & $\mathrm{X} 1.5$ & 0,763 & 0,3160 & Valid & \\
\hline & $\mathrm{X} 1.6$ & 0,723 & 0,3160 & Valid & \\
\hline \multirow{6}{*}{$\begin{array}{l}\text { Organiza } \\
\text { tional } \\
\text { Factors } \\
(\mathrm{X} 2)\end{array}$} & $\mathrm{X} 2.1$ & 0,828 & 0,3160 & Valid & \multirow{6}{*}{$\begin{array}{l}0,846 \\
\text { Reliable }\end{array}$} \\
\hline & $\mathrm{X} 2.2$ & 0,575 & 0,3160 & Valid & \\
\hline & $\mathrm{X} 2.3$ & 0,785 & 0,3160 & Valid & \\
\hline & $\mathrm{X} 2.4$ & 0,783 & 0,3160 & Valid & \\
\hline & $\mathrm{X} 2.5$ & 0,732 & 0,3160 & Valid & \\
\hline & $\mathrm{X} 2.6$ & 0,785 & 0,3160 & Valid & \\
\hline \multirow{6}{*}{$\begin{array}{l}\text { Personal } \\
\text { Factors } \\
\text { (X3) }\end{array}$} & X3.1 & 0,637 & 0,3160 & Valid & \multirow{6}{*}{$\begin{array}{c}0,838 \\
\text { Reliable }\end{array}$} \\
\hline & X3.2 & 0,827 & 0,3160 & Valid & \\
\hline & X3.3 & 0,735 & 0,3160 & Valid & \\
\hline & X3.4 & 0,840 & 0,3160 & Valid & \\
\hline & $\mathrm{X} 3.5$ & 0,745 & 0,3160 & Valid & \\
\hline & X3.6 & 0,676 & 0,3160 & Valid & \\
\hline \multirow{8}{*}{$\begin{array}{c}\text { employee } \\
\text { performan } \\
\text { ce } \\
\text { (Y) }\end{array}$} & Y.1 & 0,634 & 0,3160 & Valid & \multirow{8}{*}{$\begin{array}{c}0,893 \\
\text { Reliable }\end{array}$} \\
\hline & Y.2 & 0,883 & 0,3160 & Valid & \\
\hline & Y.3 & 0,926 & 0,3160 & Valid & \\
\hline & Y.4 & 0,489 & 0,3160 & Valid & \\
\hline & Y.5 & 0,910 & 0,3160 & Valid & \\
\hline & Y.6 & 0,912 & 0,3160 & Valid & \\
\hline & Y.7 & 0,692 & 0,3160 & Valid & \\
\hline & Y.8 & 0,692 & 0,3160 & Valid & \\
\hline
\end{tabular}

Based on the results of the analysis of validity tests in the table above, it is known that each statement indicator used has a calculated $r$ value greater than $r$ table with a level of sig 0.05 of 0.3160 . This shows that the statement of the indicators of each variable used in this study is declared valid to be used as a variable measuring instrument. Meanwhile the reliability test results in the table above, it can be seen that all variables have Apha-Cronbach values greater than 0.60 . It can be concluded that all variables used in this study are reliable. 


\section{F. Normality test}

The normality test is a test used to determine the normal or not data distribution resulting from a regression equation between the independent variable $(\mathrm{X})$ and the dependent variable $(\mathrm{Y})$.

\section{G. Multicollinearity Test}

Multicollinearity test is a test by measuring the magnitude of the correlation coefficient (r) to find out whether the level of association (closeness) in the independent variable has a relationship or influence.

\section{H. Analysis of Multiple Linear Regression}

In this study, multiple linear regression analysis was used to calculate whether the dependent variable $(\mathrm{X})$ that was influenced by the independent variable $(\mathrm{X})$ consists of $\mathrm{X} 1, \mathrm{X} 2$, and $\mathrm{X} 3$ had a large quantitative influence. According to Hasan [9] if the dependent variable (Y) is associated with an independent variable $(\mathrm{X})$ that is more than one, two, three, and so on, then the multiple linear regression formula is:

$\mathrm{Y}=\mathrm{a}+\mathrm{b} 1 \mathrm{X} 1+\mathrm{b} 2 \mathrm{X} 2+\mathrm{b} 3 \mathrm{X} 3+\mathrm{e}$

Where:

$\mathrm{Y}=$ Dependent variable is employee performance

$\mathrm{X} 1$ = Independent variable namely work stress from environmental factors

$\mathrm{X} 2$ = Independent Variables namely work stress from company factors

X3 = Independent Variables namely work stress from personal factors

$\mathrm{a}=$ Constant value

$\mathrm{b}=$ Regression coefficient $\mathrm{e}=$ disturbance term .

\section{Coefficient of Determination}

he coefficient of determination is defined as how much the ability of all independent variables in explaining the variance of the dependent variable.

\section{J. $t$-Test}

According to Ghozali [10] the t test is used to see whether there is a partial effect (each) between independent or independent variables $(\mathrm{X})$ with the dependent or dependent variable $(\mathrm{Y})$.

\section{K. F-Test}

According to Ghozali [10] the F test aims to see the effect simultaneously (together) between independent or independent variables $(\mathrm{X})$ with dependent or dependent variables (Y). In this study, the F test was used to determine the effect of the three independent variables namely environmental factors (X1), organizational factors (X2), and personal factors on the dependent variable namely employee performance (Y).

\section{RESULTS AND DISCUSSION}

\section{A. Normality Test Result}

The following are the results of the normality test using SPSS 20 in table form:

TABLE II. NORMALITY TEST RESULT

One-Sample Kolmogorov-Smirnov Test

\begin{tabular}{|ll|r|}
\hline & & $\begin{array}{r}\text { Unstandardize } \\
\text { d Residual }\end{array}$ \\
\hline $\mathrm{N}$ & Mean & 39 \\
Normal Parameters ${ }^{\mathrm{a}, \mathrm{b}}$ & Std. Deviation & $0 \mathrm{E}-7$ \\
& Absolute & .066 \\
& Positive & .066 \\
Most Extreme Differences & -.050 \\
& Negative & .414 \\
Kolmogorov-Smirnov Z & & $\mathbf{. 9 9 5}$ \\
Asymp. Sig. (2-tailed) & & \\
\hline
\end{tabular}

a. Test distribution is Normal.

b. Calculated from data.

Based on the table above, it can be seen that the value of Asymptotic Significance (2-tailed) obtained is 0.995 which indicates that the value obtained is greater than the alpha value of 0.05 so it can be concluded that all variable data are normally distributed.

\section{B. Multicollinearity Test}

The following are the results of the multicollinearity test calculated using SPSS version 20 in the form of a table:

TABLE III. MULTICOLLINEARITY TEST RESULT

\begin{tabular}{|c|c|c|}
\hline X Variable & $\begin{array}{c}\text { Tolerance } \\
\text { Value }\end{array}$ & $\begin{array}{c}\text { VIF } \\
\text { Value }\end{array}$ \\
\hline $\begin{array}{c}\text { Environmental } \\
\text { Factors (X1) }\end{array}$ & 0.575 & 1,739 \\
\hline $\begin{array}{c}\text { Organizational } \\
\text { Factors (X2) }\end{array}$ & 0,331 & 3,025 \\
\hline Personal Factor & 0,332 & 3,015 \\
\hline (X3) &
\end{tabular}

So, the results of multicollinearity tests in the regression model can be taken as follows:

1. There are no problems or symptoms of multicollinearity in environmental factor variables (X1) because the tolerance value is $0.575>0.1$ and the VIF value is $1.739<10$.

2. There are no problems or symptoms of multicollinearity in organizational factor variables (X2) because the tolerance value is $0.331>0.1$ and the VIF value is $3.025<10$.

3. There are no problems or symptoms of multicollinearity in personal factor variables (X3) because the tolerance value 
is $0.332>0.1$ and the VIF value is $3.015<10$.

\section{Multiple Linear Regression Analysis Result}

The following are the results of the calculation of multiple linear regression analysis using SPSS version 20 in table form:

TABLE IV. MULTIPLE LINEAR REGRESSION ANALYSIS TEST RESULT

\begin{tabular}{|c|c|c|c|c|c|c|}
\hline \multicolumn{7}{|c|}{ Coefficients $^{\mathrm{a}}$} \\
\hline & \multirow[t]{2}{*}{ Model } & \multicolumn{2}{|c|}{$\begin{array}{l}\text { Unstandardized } \\
\text { Coefficients }\end{array}$} & \multirow{2}{*}{$\begin{array}{c}\begin{array}{c}\text { Standardize } \\
\mathrm{d}\end{array} \\
\text { Coefficients } \\
\text { Beta } \\
\end{array}$} & \multirow[t]{2}{*}{$\mathrm{t}$} & \multirow[t]{2}{*}{ Sig. } \\
\hline & & B & Std. Error & & & \\
\hline \multirow[t]{4}{*}{1} & (Constant) & -11.741 & 3.770 & & -3.114 & .004 \\
\hline & $\begin{array}{l}\text { Environmental } \\
\text { Factors }\end{array}$ & .527 & .258 & .226 & 2.042 & .049 \\
\hline & $\begin{array}{l}\text { Organizational } \\
\text { Factors }\end{array}$ & .588 & .354 & .243 & 1.661 & .106 \\
\hline & Personal Factors & 1.201 & .356 & .493 & 3.378 & .002 \\
\hline
\end{tabular}

Based on the results of the analysis that has been done, the regression equation formed is as follows:

$$
Y=-11,741+0,527 X_{1}+0,588 X_{2}+1,201 X_{3}
$$

\section{Coefficient of Determination Result}

The following are the results of the calculation of coefficient of determination analysis using SPSS version 20 in table form:

\section{TABLE V. COEFFICIENT OF DETERMINATION RESULT}

\begin{tabular}{|l|r|r|r|c|}
\hline \multicolumn{7}{|c|}{ Model Summary } \\
\hline Model & \multicolumn{1}{|c|}{$\mathrm{R}$} & R Square & $\begin{array}{c}\text { Adjusted R } \\
\text { Square }\end{array}$ & $\begin{array}{c}\text { Std. Error of the } \\
\text { Estimate }\end{array}$ \\
\hline 1 & $.867^{\mathrm{a}}$ & .752 & .731 & 2.774 \\
\hline
\end{tabular}

a. Predictors: (Constant), Environmental Factors, Organizational

Factors, Personal Factors

b. Dependent Variable: Employee Performance

The decision is the environmental factor variable (X1), the organizational factor variable (X2), and the personal factor variable (X3) has an effect of $75.2 \%$ on the Employee Performance variable (Y).

\section{E. $t$-Test Result}

Based on table 4 above, the t test results can be decided that:

1. For the results of the decision of the first hypothesis of environmental factors variables (X1) obtain the value of $\mathrm{t}$ count> table $(2,042>2,00)$ and significant value $(0,049$ $<0,05)$ means that $\mathrm{H} 0$ is rejected and $\mathrm{H} 1$ is accepted that there is a positive and significant influence between environmental factors on employee performance at PT. BPRS Syarikat Madani, Batam city.

2. For the results of the decision of the second hypothesis of the organizational factors variable (X2) obtain the value of t count $<\mathrm{t}$ table $(1.661<2.00)$ and significant value $(0.106>$ 0.05 ) means that $\mathrm{H} 0$ is accepted and $\mathrm{H} 2$ is denied that there is a positive effect and not significant between organizational factors on employee performance at PT. BPRS Syarikat Madani, Batam city.

3. For the results of the decision of the third hypothesis of the personal factors variable (X3) obtain the value of $t$ count $>t$ table $(3.378>2.00)$ and significant value $(0.002<0.05)$ means that $\mathrm{H} 0$ is rejected and $\mathrm{H} 3$ is accepted that there is a positive effect and significant between personal factors on employee performance at PT. BPRS Syarikat Madani, Batam city.

\section{F. F Test Result}

The following is the result of the calculation of the F test using the SPSS version 20 program in table form:

TABLE VI. F TEST RESULT

\begin{tabular}{|l|r|r|r|r|r|}
\hline Model & Sum of Squares & df & \multicolumn{1}{|c|}{$\begin{array}{c}\text { Mean } \\
\text { Square }\end{array}$} & F & Sig. \\
\hline Regression & 818.560 & 3 & 272.853 & 35.457 & $.000^{\circ}$ \\
$1 \quad$ Residual & 269.337 & 35 & 7.695 & & \\
Total & 1087.897 & 38 & & & \\
\hline
\end{tabular}
a. DependentVariable: Employee Performance
b. Predictors: (Constant), Environmental Factors, Organizational Factors,
Personal Factors

From the output above the value of fcount $>$ ftabel (35.457> $2.87)$ and significant value $(0,000<0.05)$ means that Ho is rejected and $\mathrm{Ha}$ is accepted that there is a positive and significant effect together between environmental factors, organizational factors, personal factors on employee performance at PT. BPRS Syarikat Madani, Batam city.

\section{G. Discussion}

Based on the results of the study and the results of statistical test calculations using multiple linear regressions, it can be seen that the obtained constant value is equal to -11.741 , where the results obtained are negative constants which means a performance decrease of -11.741 if the other variables are considered constant. Regression coefficient on environmental factor variable (X1) is 0.527 is positive, and then work stress on environmental factors has a positive effect on employee performance if the other variables are constant. Regression coefficients on organizational factor variables (X2) of 0.588 are positive, so work stress on organizational factors has a positive effect on employee performance if the other variables are constant. The regression coefficient on the personal factor variable (X3) of 1,201 is positive, and then work stress on personal factors has a positive effect on employee performance if the other variables are constant.

Then, based on the results of hypothesis testing on the t test, that for the results of the decision of the first hypothesis of environmental factor variables (X1) that there is a positive and significant influence between environmental factors on the performance of employees at PT. BPRS Syarikat Madani, Batam city. For the results of the decision of the second hypothesis of the organizational factor variable (X2) that there is a positive and not significant effect between organizational factors on the performance of employees at PT. BPRS Syarikat Madani, Batam city. For the results of the decision of the third hypothesis from the personal factor variable (X3) that there is a positive and significant influence between personal factors on the performance of employees at PT. BPRS Syarikat Madani, 
Batam city. Furthermore, based on the results of the calculation of the hypothesis test using the F test, there are positive and significant effects together between environmental factors, organizational factors, and personal factors on the performance of employees at PT. BPRS Syarikat Madani, Batam city.

\section{CONCLUSIONS \& RECOMMENDATIONS}

\section{A. Conclusions}

Based on the results of the research described in the previous chapter, conclusions can be taken as follows:

1. There is a positive and significant influence between environmental factors on the performance of employees at PT. BPRS Syarikat Madani city of Batam as evidenced by the results of the $t$ test.

2. There is a positive and not significant influence between organizational factors on the performance of employees at PT. BPRS Syarikat Madani Batam city is proven by the results of the t test.

3. There is a positive and significant influence between personal factors on employee performance at PT. BPRS Syarikat Madani Batam city is proven by the results of the $t$ test.

4. There is a positive and significant influence together between environmental factors, organizational factors, and personal factors on employee performance at PT. BPRS Syarikat Madani Batam city as evidenced by the F test results.

\section{B. Recommendations}

Based on the results of the research and conclusions, the suggestions that can be submitted are as follows:

1. For companies, PT. BPRS Syarikat Madani kota Batam, both the head office and branch offices need to supervise, pay attention, and maintain the level of stress experienced by employees so that they are in a stable condition and tend to lead to increased employee performance. In addition, the company must be able to direct and provide input that can inspire and motivate employees to work better than before.

2. For further research, there are three recommendations for further research that will be submitted by the author. First, further research is expected to be able to add or use other research variables so that future research can be used as a comparison so that the results can be better understood. Second, future research should use other company objects as research locations so that the results of the research can be compared with the results of previous studies. Third, it is recommended that future studies assess objectively employee performance variables, namely employee performance variable questionnaires, which are answered by those who assess the performance of employees in the company to be studied.

\section{REFERENCES}

[1] S. P. Robbins and T. A. Judge, Perilaku Organisasi, Jakarta: Salemba Empat, 2008.

[2] R. L. Mathis and J. H. Jackson, Human Resource Management, United States: Cenange-Learning, 2010.

[3] T. H. Handoko, Manajemen Personalia, Yogyakarta: BPFE Yogyakarta, 2008.

[4] Sedarmayanti. Perencanaan dan Pengembangan Sumber Daya Manusia Untuk Meningkatkan Kompetensi, Kinerja, dan Produktivitas Kerja, Bandung: Refika Aditama, 2017.

[5] S. P. Robbins, Manajemen (Edisi 11), Jakarta: PT. Indeks, 2012.

[6] T. H. Handoko, Manajemen Sumber Daya Manusia, Yogyakarta: BPFE UGM, 2009.

[7] M. Nazir, Metode Penelitian, Bogor: Ghalia Indonesia, 2014.

[8] Sugiyono, Metode Penelitian Pendidikan : Pendekatan Kuantitatif, Kualitatif, dan R\&D, Bandung: Alfabeta, 2017.

[9] M. I. Hasan, Pokok-Pokok Materi Statistik 1 (Statistik Deskriptif), Jakarta: Bumi Aksara, 2008.

[10] Ghozali, Aplikasi Analisis Multivariate dengan Program IBM SPSS, Semarang: Universitas Diponegoro, 2012. 